This is an Accepted Manuscript of an article published by Taylor \& Francis in Defense and Security Analysis, Volume 36, 2020 - Issue 2 on 20 Apr 2020, available online:

http://www.tandfonline.com/10.1080/14751798.2020.1750186. 


\title{
The Czech Defence and Security Industry: Taking the Pulse to an
} Ailing Man

\author{
Bohuslav Pernica, ORCID 0000-0002-1087-6888 \\ Institute of Regional and Security Sciences, Faculty of Economics and Administration, \\ University of Pardubice, Pardubice, the Czech Republic
}

\begin{abstract}
Covering the period of 1990-2020, the paper summarises the evolution of the iron triangle of the mutual relationships amongst the Ministry of defence, defence industry, and political elite, in the post-communist Czech Republic, In essence, the essay stresses the oddness of this relationship. On the one hand, the government is bound by a partnership to the Defence and Security Industry Association of the Czech Republic (DSIA), a lobbying group of more than 100 organisations that conduct business in defence and security sector in the Czech Republic. Yet, since its creation in 2000, this assemblage of industries within DSIA's market position is falling, in fact. Neither political parties in power, nor the governments have been able to support the national defence industry through the military. Although some subsidiaries of multinational armament concerns are DSIA members, the transnational military-industrial complex utilises DSIA only as a proxy for distribution their products in the Czech Republic with the assistance of national military elite. Just a few DSIA national members are able to compete internationally with their cutting edge products. Others have evolved into middlemen trading in Soviet and Czechoslovak equipment retired from the Czech Armed Forces in effect.
\end{abstract}

Keywords: Czech Republic; defence industry; lobbying; military procurement

\section{Introduction}

The end of the Cold War in Czechoslovakia entailed not only the definite collapse of the Soviet plans for an expansion of communism towards the West, ${ }^{1}$ but it implied the end of large, conscripted armed forces. The armed forces of Warsaw Pact, previously subordinated to Moscow, ${ }^{2}$ started shrinking almost immediately and lost their privileged 
omnipresent social and economic positions from societal and economic institutions. ${ }^{3}$. In their place, new conceptual models were adopted that stressed volunteer/professional forces, with the new objective of deploying under the flag of the UN or NATO to outof-area operations in case of regional crises that had to be sustainable for months, or even years. ${ }^{4}$ The radical change to the polity and economic system in the Czech Republic, as well as the systematic change in the aim, model, and size of the military transfigured not only civil-military relations ${ }^{5}$, but caused an evolution of the paradigm of relations amongst the military, the defense ministry's bureaucracy, the country's political elite, as well as with a large defence industry still built-up in the Soviet style.

The aim of this paper is to summarise this 30-year-evolution of Czech defense industry from a state of autarky to one that is now a mutual vendor in regional militaryindustrial complex. This evolution will show, in effect, that the military is the feeblest side in the iron triangle as G. Adams ${ }^{6}$ named the knot of mutual relations amongst the stakeholders shaping the U.S. defence and security policy. The ambition of this diachronic case study is to address three research questions:

1. What are the connections and nature of Czech defence industry to the Ministry of Defence and armed forces like?

2. Can Czech defence industry meet the requirements of the Czech Armed Forces (CAF)?

2.3.How difficult is it for officials to procure equipment and services for the CAF?

\section{De/militarisation, conversion, and peace-dividend}

Czechoslovak defence industry originated in the early 1950s by A. Čepička, the defence minister in K. Gottwald's government and his son-in-law, in response to a J. Stalin's wish during a secret meeting in Moscow. ${ }^{7}$ The Soviet plan on an establishing of 
a military-industrial complex (MIC) according to Soviet patterns in Czechoslovakia was revealed only after the dismissal of Čepička from his office in 1956. If defence spending in 1950 accounted for $6 \%$ of national income, this amount grew to $18 \%$ of national income by 1953. The Čepička secret military imperio in imperium placed considerable strains on the national economy and endangered the popularity of communism as the production of consumer goods, had to be sacrificed for military kit. ${ }^{8}$ In time, this imbalance in manufacturing was addressed in favour consumer goods in the 1960s. ${ }^{9}$

The only advantage of Čepička's defence plan was the reinforcement of military autarky which produced for Czechoslovakia no small degree of soft power. Due to the fact, that the Soviets were willing to transfer production of Soviet tanks, armoured vehicles, and jet aircraft to Czechoslovakia in order to increased modernisation of Warsaw Pact forces, small Czechoslovakia become a significant military equipment exporter. According to L. Štrougal, a Czechoslovak prime minister of many years standing, defence industry generated at least 3\% of GDP. ${ }^{10}$ The Soviets not only allowed the production of Soviet-designed military equipment in Czechoslovak factories ${ }^{11}$, but also they permitted $R \& D$ and indigenous modernisation. In particular, upgrades of T-55 tanks and their conversion to field support vehicles were requested by customers. ${ }^{12}$ Importantly, Czechoslovakia was the first country where MiGs were manufactured. ${ }^{13}$

Later on, the Soviets consented to the development of training jet aircraft which became the standard in the second world for pre-training before the airman's shift to interceptors or supersonic bombers. In 1962, the Soviets announced that it would procure $1,600 \mathrm{~L}-29$ aircraft by $1965 .{ }^{14}$ In response to specialisation plans within the Council for Mutual Economic Assistance (COMECON), Czechoslovakia could develop, produce, and sell artillery systems (e.g., self-propelled artillery ShKH model 
77 “DANA”), self-propelled anti-aircraft guns (e.g., PLDvK Model 53/59 - 1 "Lizard"), sensors (e.g., the "TAMARA” passive radar), small passenger aircraft (e.g., L-410), explosives, small-arms ammunition, light weapons (e.g., Semtex, 9mm handguns, 7.62mm assault rifle model 58, Czechoslovak machine pistol model 61 "Skorpion”), and heavy lorries (e.g., Tatra). The Tatra chassis was hugely successful and become a standard within Warsaw pact inventory. For instance, the chassis became the basis for the amphibious, armoured personnel carrier $(8 \times 8)$ OT-64 SKOT, and multiple rocket launcher RM-70. As defence industry was so important for Czechoslovakia, that Czechoslovak delegates to the COMECON regularly championed this specialisation. ${ }^{15}$

In 1993, the Czech Republic was assessed by SIPRI as the number seven within the top ten of arms exporting countries. Despite this fact, neither Czech nor Slovak defence industry manufacturing was listed within the hundreds of the outstanding defence and security producers. ${ }^{16}$ Nonetheless, this state of military autarky of Czechoslovakia's defence industry was probably a virtue of necessity. The COMECON was a vehicle of post-war reconstruction directed by the Soviet Union. As war reparations, hundreds of factories in Hungary, Poland, Romania, Bulgaria, and East Germany were sequestrated and their machinery transferred to the Soviet Union. ${ }^{17}$ From the point of view of Soviets, the only excess industrial capacity for the rearmament of the Warsaw Pact was located in Czechoslovakia whose industry was not affected by the WWII. This industrial capacity was considerable after being its expansion during WWII and Soviets happily employed it in support of their imperial policy during the Cold War.

The production of heavy weaponry was shifted from the Czech Republic to Slovakia during the communism period. ${ }^{18}$ However, this industrial capacity vanished as a consequence of the implementation of the Treaty of Treaty on Conventional Armed Forces in Europe (CFE) ${ }^{19}$ Conversely, the Czech Republic decided to specialise in 
defence $R \& D$ in order protect some unique production. These industries were concentrated in state-owned enterprises and were designed to provide all aspects of maintenance logistic support, as well as modernization. ${ }^{20}$ Thus, these state-owned enterprises enjoyed a high-level of monopolistic position vis-à-vis their client armed forces. After the Velvet Divorce and as a consequence of the CFE treaty, the Czech government determined that this industry should be privatized due to the retirement of this Cold War military equipment. The privatization was planned to be completed by the end of $1995 .^{21}$

\section{The road to the vest-pocket military-industrial complex}

The Czech defence and security industry coalesced in 1992 following the break-up of Czechoslovakia. As a group of both privatised and state-owned enterprises located on Czech territory (see Table 1), they were considered to be an essential element of mobilisation planning of the CAF.

\section{[Table 1 SOMEWHERE HERE]}

The mid-1990s was a milestone in the evolution of the relations within the iron triangle. The Czech Republic had fulfilled its commitments agreed under the CFE treaty when reduced the size of the CAF to the CFE ceilings. A substantial portion of the surplus of the CFE equipment was sold to arms dealers as scrap in order to compensate the staggering reduction of the national military demand. This equipment was often upgraded in private defence industry and re-sold with a significant private profit to Africa and Asia. ${ }^{22}$ To that extent that privatised enterprises weathered the conversion in the early 1990s, these now private companies were expecting the CAF to modernised in 
consequence of its new peacekeeping deployments in the former-Yugoslavia and in anticipation of NATO enlargement sooner or later. ${ }^{23}$. In order to show good faith the MOD developed its first post-Cold War armament plan. The document was sold to the public as a crucial result of the newly adopted American planning, programming, and budgeting system (PPBS). ${ }^{24}$

Although the classified armament plan, a component of the Concept of the CAF's Modernisation, was discussed in the Parliament on March 23, 1995, this 1,200page document was shredded by January $31,1997 !^{25}$ The MOD provided an unclassified extract as a MOD Bulletin for Czech Defence Industry. ${ }^{26}$ The only issue reflecting experience gained in the out-of-area operations in the Bosnia and Hercegovina was a request for the procurement of wheeled armoured vehicles. The new vehicles should be delivered to the CAF by 1997 at the latest and should cost ca 2.4 CZK billion. In general, the armament plan of 1995 expected that the CAF would spend on the modernization some 120 CZK billion between 1995 and 2005. On the weaponry and other military needed matériel only $63.4 \%$ of the needed amount was allocated. In particular, the MOD stressed the need of issues of conventional warfare. More than $12 \%$ of the armament budget for the next 10 fiscal years was intended to be spent on aerial bombs, anti-tank missiles, air-to-air and air-to-ground missiles, APFSDS munition, etc.

This plan on the further development of the CAF was based still on former communist military planning assumptions and yet it attracted the attention of industrial giants, such as ČKD, RDG Group, and Přerovské strojírny, which were privatised on credit to their top management, but those holdings were facing the loss of markets. They believed that_NATO enlargement will offer the same opportunity for national manufacturers than the Warsaw Pact did in the 1990s. At the same time, the retirement of generals, and higher commanders with Soviet background continued in the CAF. 
Being retired from the General Staff of the CAF, the post-communist military elite searched for a civilian career. Enjoying an ill-founded reputation for being military experts in defence planning, some of them were hired by democratic political parties and assigned as advisers to defence ministers to provide them with advice on how to shape the CAF, e.g., general L._Jura, the former commander of the Military Circle "WEST". ${ }^{27}$ Other generals, as insiders, took advantage of the upcoming military matériel modernisation. Passing through the revolving door, they wanted to become lobbyists.

The most influential person was K. Kuba, a son of a communist colonel and the first supreme inspector of the ground forces ${ }^{28}$, who land the post of secretary general of the Defence Industry Association (DIA), one of two advocacy group established in the Czech Republic in 1997 in order to lobby for specific armament projects. DIA was established by the R. Háva, a proprietor of Omnipol, a former state-owned enterprise trading in defence and security matériel, and supported by former deputy defence minister M. Kalousek. ${ }^{29}$ The rivalry lobbing organisation also named DIA too, was established by J. Maroušek, the owner of ČKD holding and RDP Group, a holding company, which in 1993, employed some 200,000 people in 40 companies. ${ }^{30}$ Moreover, K. Kuba was employed as an adviser to M. Lobkowitz, a pro-Atlantic defence minister in M. Tošovský's interim government, with the task of drafting a strategic concept for the CAF during this six-month period. ${ }^{31}$ Whilst this document was eventually suspended by Lobkowitz's successor, V. Vetchý in $1998^{32}$, the high industrial circles and the high political circles ${ }^{33}$ merged into harmony.

M. Zeman, prime minister in minority left-wing government, tasked his defence minister, V. Vetchý ${ }_{2}$ to establish a partnership with DIA in order to defend the interests of the country's defence industry. The partnership was legalised one year after NATO 
enlargement by governmental resolution No 259, On Principles of Collaboration with the National Defence Industry. According to this document, the MOD should forge an agreement with Hava's DIA until June 30, 2000. The Ministry of Foreign Affairs was to support DIA diplomatically until September 30, 2000 and the Ministry of Industry and Trade to launch a programme of providing soft loans for DIA members in 2001. The agreement was envisaged to last for ten years.

As this policy was broadly similar to that enjoyed by U.S. defense industry, ${ }^{34}$ members of the Parliament came to accept it. In particular, the social democrats, who ruled the country in 1998-2002, fostered the new relationship with DIA. Some of these parliamentarians (e.g., M. Titz) was listed by DIA as an honorary member of the editorial board of the Czech Defence Industry and Security Review, a P.R. magazine issued by the Defence and Security Industry Association (DSIA), a successor of DIA. Taking into account the 1995 armament plan, Zeman's government boosted its support to defence industry by the adoption of resolution No 560D in June 9, 1999. According to which, the MOD's budget should not fall under 2.2 per cent of GDP from 2000. The 2 per cent target was defended by the government's plan to create a professional force and end conscription by 2006 as well as by a radical modernization of the CAF by $2010 .{ }^{35}$ The plan was initiated in 1991 , and was known as Plan $2005 .{ }^{36}$

That said, military expenditures have never reached the 2 per cent target ${ }^{37}$ and, as presented in the Appendix A, the shift to a professional force has had a deleterious effect on DIA's members. As such, DIA was renamed DSIA in order to gain a wider market, i.e., the Ministry of the Interior which is in charge of police and fire brigades became a new partner. In consequence, the political-military ambition of 1997 and the armament plan of 1995 have proven to be illusionary. Currently, DSIA consists of 126 entities as presented in the Figure 1. 
[Figure 1 SOMEWHERE HERE]

The majority of DSIA's members are out of the public ownership, but are not sufficiently large to be listed of a stock exchange. The only opportunity to assess their financial viability is to access whichever information is reported in the Public Register administered by the Ministry of Justice. Yet, a lot of entities do not publish timely information. What is known about DSIA's members is that they capital-starved, thereby making it risky to trade with them. In general, many of them have no organic industrial capacity and their main business is not in the security, or defence sectors. For instance, GORDIC spol. s r.o., a limited liability software company conducting business with accounting software for public sector, is a DSIA member because the MOD is using its software since 1994 and this supplier relation is a vendor lock-in.

Surprisingly, but in accordance with the president Eisenhower's definition of the military-industrial complex ${ }^{38}$, a DSIA member is the city of Brno, the second largest municipality in the Czech Republic. Brno holds the majority share ownership in Veletrhy Brno, a.s., the main organiser of trade fairs in the Czech Republic. Veletrhy Brno, a.s. organises the IDET - International Defence and Security Technologies Fair every other year. More than a half of IDET budget is covered by taxpayers' money. With the budget of $60 \mathrm{CZK}$ million, IDET is considered as the second most profitable entity of Veletrhy Brno, a.s.

[Table 2 SOMEWHERE HERE] 
In spite of the public support presented during the IDET, the fair has been organised since the early 1990s as a shop window of Czech defence industry. Yet, defence industry's markets and its products are fading as presented in the Table 2. Notwithstanding this clear financial reality, the MOD revalidated its partnership in 2010 for the next ten year with tacit blessing of the right-wing government. ${ }^{39}$ Surprisingly, the MOD supports DSIA membership of the University of Defence, a part of the MOD organization, and the membership of four state-owned enterprises sub-ordinated to the MOD. Thus, those elements of the defence institution may find themselves in the position of lobby against the MOD. Thus, contrary to its 1993 objectives and intentions presented, DSIA is not providing value to the Czech taxpayer or furthering Czech governments' policies and objectives.

In order to demonstrate public support to defence and security industry, all patriotic political parties (communists, socialists, civic and Christian democrats) established within the Parliamentary Chamber Body responsible for defence policy (Committee on Defence) a specific sub-committee to address the issue of military modernisation. Despite the general concern of all political parties, the procurement by the CAF of domestic products has not gone well. Procurements have all been behind schedule. For example, wheeled transporters should be delivered in 1997 according to the armament plan of 1995; however, the last Pandur 8x8 vehicle was finally delivered in 2009. Also tenders have suffered from corruption, e.g., the procurement of Gripen JAS-39 interceptors in the 2000s. ${ }^{40}$

In general, the MOD is usually not able to undertake procurements in accordance with endorsed plans. Sometimes military equipment is delivered for more than seven, ten, fifteen fiscal years behind schedule due to consistently poor defence planning, frequent changes in the government, and lobbying of military suppliers 
through both political parties and with military leadership. In response to lobbying through political parties, political parties apply a patronage to particular project. This corruption slows down the procurement because political parties strive to manipulate strategic documents, such as strategic concepts, in order to legitimize the MOD policy before funding is secured and agreed. The military is seen as a vehicle for maximisation of the political profit. So, the military elite is permitted to ask for unfeasible politicalmilitary ambition because the number of uniforms, guns, etc. put to public procurement is determined by the end-state planned by the military. With tacit consent among political parties, an accomplishment of the goals justified by governmental policy is delayed, to be addressed by a future government. So, the military feels free to exaggerate its political-military ambition in order to accommodate the demands of ruling political parties.

But lobbying through the military produces impractical defence plans as presented in Appendix A as well as it supports the conceptual spaghetti ${ }^{41}$ established in the 1990s. A shining example is the idea to build-up the third infantry brigade scheduled for completion in 2025 . The brigade was disestablished in 2002 due to lack of money, ${ }^{42}$ but the political parties accepted the MOD's strategic concept of 2015 to make an attempt of re-building it up in the next ten years. How this plan can be considered to be feasible in light of basic demographic conditions and projections ${ }^{43}$ of the Czech Republic must be judged problematic.

\section{Conclusion}

Although the political elite shows a continuous concern for defence industry and the military, the iron triangle experiences a break-down: the military keeps failing in meeting the goals and objectives set by endorsed defence plans, corrupted political elite benefit little from the patronage of specific projects due to an incapability of ministerial 
bureaucracy to produce costed and executable defence plans, all the while Czech defence and security industry shrinks. Clearly, successive governments' strategic thinking remains based on a nostalgia for elements and concepts of the communist period, which undermines the ability of the CAF to field modern capabilities, under an opaque layer of incompetence of governance and corruption.

\section{Notes}

\section{Disclosure statement}

No potential conflict of interest was reported by the author.

\section{Notes on contributor}

Bohuslav Pernica, lieutenant colonel (ret.), studied at the Military Academy of the Ground Forces in Vyškov and at the Faculty of Social Sciences, the Charles University in Prague. As an analyst in strategic management and defence and security policy, he concluded his military career as the military adviser to deputy minister; he co-edited the White Paper on Defence in 2011. As a freelance researcher focusing on defence planning matters, he comments problems of national defence and security policy at the On War On Peace blog since 2010. 
Appendix A The size of the Czech military according to the CFE treaty and the political-military ambition, 1993-2019. ${ }^{44}$

\begin{tabular}{|l|l|l|l|l|l|l|}
\hline \multirow{2}{*}{$\begin{array}{c}1993 \\
\text { ceilings }\end{array}$} & tanks & ACVs & APs & CAC & AHs & manpower \\
\cline { 2 - 7 } & 957 & 1,367 & 2,262 & 230 & 50 & 93,333 \\
\hline \multirow{2}{*}{1997} & tanks & ACVs & APs & CAC & AHs & manpower \\
\cline { 2 - 7 } & 952 & 1,367 & 767 & 143 & 36 & 61,647 \\
\hline
\end{tabular}

until the NATO enlargement: GF: two brigades; the Rapid Response Brigade is able to taking part in any kind of NATO ops under the UN mandate); AF: two helicopter squadrons (after the NATO enlargement: GF: the Rapid Response Brigade; AF: one squadron of MRCA + one helicopter squadron)

\begin{tabular}{|l|l|l|l|l|l|l|}
\hline \multirow{2}{*}{1999} & tanks & ACVs & APs & CAC & AHs & manpower \\
\cline { 2 - 7 } & 938 & 1,219 & 754 & 114 & 34 & 61,948 \\
\hline
\end{tabular}

since 2000: GF: one infantry brigade plus (the Rapid Response Brigade) able to be deployed within NATO territory by use of strategic lift provided by allies $+1,000$ soldiers deployable as one mechanized battalion and one specialized company; AF: -

\begin{tabular}{|l|l|l|l|l|l|l|}
\hline \multirow{2}{2}{2002} & tanks & ACVs & APs & CAC & AHs & manpower \\
\cline { 2 - 7 } & 622 & 1,241 & 585 & 112 & 34 & 49,491 \\
\hline
\end{tabular}

since 2006: GF: EITHER 5,000 soldiers as one (rapid response) brigade $+1,000$ soldiers rotated as one battalion +250 soldiers deployable only for six months; AF: OR an air force equivalent (a brigade) deployable (from 2007) for six months without any rotation + air force equivalent (a battalion)

\begin{tabular}{|l|l|l|l|l|l|l|}
\hline \multirow{2}{*}{2003} & tanks & ACVs & APs & CAC & AHs & manpower \\
\cline { 2 - 7 } & 541 & 1,235 & 528 & 125 & 34 & 54,615 \\
\hline
\end{tabular}

since 2010: GF: EITHER 3,000 soldiers as a core of a mechanized brigade deployable (from 2007) for six months without any rotation OR 1,000 soldiers deployable as a battalion for six months without any rotation AND 250 soldiers deployable with rotation/a Role3 Field Hospital; AF: OR air force equivalent (a brigade) deployable (from 2010) for three months without any rotation

\begin{tabular}{|l|l|l|l|l|l|l|}
\hline \multirow{2}{*}{2007} & tanks & ACVs & APs & CAC & AHs & manpower \\
\cline { 2 - 7 } & 181 & 580 & 321 & 38 & 38 & 40,124 \\
\hline
\end{tabular}

since 2008: GF: EITHER a brigade task force (article V NATO Treaty) deployable for six months without any rotation OR a battalion task force deployable for six months with any rotation + a brigade command for 12 months without any rotation + SMEs with rotation + NRF; AF: OR air force (article V NATO Treaty) equivalent (a brigade) deployable for six months without any rotation

\begin{tabular}{|l|l|l|l|l|l|l|}
\hline \multirow{2}{*}{2008} & tanks & ACVs & APs & CAC & AHs & manpower \\
\cline { 2 - 7 } & 179 & 515 & 317 & 42 & 38 & 38,805 \\
\hline
\end{tabular}

since 2010: GF: a brigade task force (article V NATO Treaty) deployable for six months without any rotation AND a battalion task force deployable for six months with rotation AND a brigade command for 12 months without any rotation OR only SMEs with rotation whenever the Czech Republic is taking part in NRF and the brigade task force was deployed; AF -

\begin{tabular}{|l|l|l|l|l|l|l|}
\hline \multirow{2}{*}{2011} & tanks & ACVs & APs & CAC & AHs & manpower \\
\cline { 2 - 7 } & 166 & 494 & 244 & 38 & 25 & 38,805 \\
\hline
\end{tabular}

since 2015: a confirmation of ambition of 2007 by civilian experts in defence and security policy, but a warning was expressed on honesty of contribution

\begin{tabular}{|l|l|l|l|l|l|l|}
\hline \multirow{2}{*}{2012} & tanks & ACVs & APs & CAC & AHs & manpower \\
\cline { 2 - 7 } & 164 & 528 & 194 & 38 & 24 & 33,546 \\
\hline \multicolumn{5}{|l}{ since 2015: GF: a brigade task force (article V NATO Treaty) deployable for six } \\
\hline
\end{tabular}


months without any rotation AND a battalion task force deployable for six months with rotation AND company task force with rotation AND a battalion (NRF) AND SMEs; AF: OR air force equivalent (a battalion) deployable for six months without any rotation

\begin{tabular}{|l|l|l|l|l|l|l|}
\hline \multirow{2}{*}{2017} & tanks & ACVs & APs & CAC & AHs & manpower \\
\cline { 2 - 7 } & 120 & 439 & 179 & 35 & 17 & 36,131 \\
\hline
\end{tabular}

since 2020: GF: in case of war, the Czech Armed Forces; a brigade task force (article V NATO Treaty) deployable for six months without any rotation OR battalion task force deployable for six months with rotation AND a company task force with rotation AND one battalion (NRF); AF: AND air force (article V NATO Treaty) equivalent (a brigade) deployable for six months without any rotation

\begin{tabular}{|l|l|l|l|l|l|l|}
\hline \multirow{2}{*}{2019} & tanks & ACVs & APs & CAC & AHs & manpower \\
\cline { 2 - 7 } & 116 & 437 & 179 & 36 & 17 & 36,729 \\
\hline
\end{tabular}

Since 2025: a confirmation of ambition of 2017, a confession of a shipwreck of defence planning

Notes:

GF... ground forces, AF ... air forces, ACVs... armoured combat vehicles,

Aps... artillery pieces, CAC... combat aircraft, AHs... attack helicopters, manpower...

the number of personnel reported by the MOD (due to the fact, that the Czech Republic reports as manpower civilians since 2005 , the number of soldiers is much more smaller and differs significantly from figures presented by the Military Balance publications). 
Table 1. The Czech Republic: privatized and the state-owned enterprises as a base of the Czech Armed Forces' mobilization capabilities in 1993. ${ }^{45}$

\begin{tabular}{|c|c|}
\hline Privatized enterprises & Government's owned enterprises \\
\hline 1. Zeveta Bojkovice, a.s. & 1. Letecké opravny Kbely, Praha \\
\hline 2. Poličské strojírny Polička & 2. Letecké opravny Malešice, Praha \\
\hline 3. Selier \& Bellot Vlašim, a.s. & 3. Naše vojsko, Tiskárna Praha \\
\hline 4. Tesla Pardubice & 4. Vojenské lesy a statky Praha \\
\hline 5. Avia, a.s. Praha & 5. Vojenské stavby Praha \\
\hline 6. Transporta Chrudim & 6. VOP 011 Mostkovice \\
\hline 7. Česká zbrojovka Uherský Brod, a.s. & 7. VOP 012 Nový Jíčín - Bludovice \\
\hline 8. Česká zbrojovka Vsetín & 8. VOP 013 Horka na Moravě \\
\hline 9. Zbrojovka Brno, a.s. & 9. VOP 014 Uherský Brod \\
\hline 10. Meopta Přerov & 10. VOP 025 Nový Jíčín \\
\hline 11. BSS Mataco, a.s. Brandýs n. Labem & 11. VOP 026 Sternberk \\
\hline 12. Tesla Strašnice, a.s. & 12. VOP 042 Dolní Bousov \\
\hline 13. Lites, a.s. Liberec & 13. VOP 042 Olomouc \\
\hline 14. Rotter, s. s r.o. Vír na Moravě & 14. VOP 064 Hradec Králové \\
\hline 15. Sigma Hranice, a.s. & 15. VOP 065 Český Těšín \\
\hline 16. Elektrosignál Praha & 16. VOP 081 Přelouč \\
\hline 17. Gumárny Zubří & 17. VOP 082 Kutná Hora \\
\hline 18. A. G. U.-Int. Přelouč & 18. VOP 083 Český Dub \\
\hline 19. AQC, s. s r.o. Praha & 19. VOP 084 Olomouc \\
\hline 20. Chirana OTS, a.s. Praha & 20. Vojenský projektový ústav Praha \\
\hline \multicolumn{2}{|l|}{ 21. KPS Moravské Budějovice } \\
\hline \multicolumn{2}{|l|}{ 22. Tesla Praha } \\
\hline 23. ZMA Ostrov nad Ohří & \\
\hline
\end{tabular}

Notes:

VOP... Vojenský opravárenský podnik (the military central repair shop) 
Table 2. The IDET (International Defence and Security Technologies Fair), 1999_ 2019.46

\begin{tabular}{|c|c|c|c|c|c|c|}
\hline \multirow[t]{3}{*}{ Year } & \multicolumn{3}{|c|}{ exhibition space, m2 } & \multicolumn{2}{|c|}{ number of exhibitors } & \multirow{3}{*}{$\begin{array}{c}\text { number of visitors } \\
\text { total }\end{array}$} \\
\hline & & incl. & incl. foreign & & cl. the Czech & \\
\hline & total & lisplay & exhibitors & total & Republic & \\
\hline 1999 & 12,476 & N/A & N/A & 269 & 118 & 10,076 \\
\hline 2001 & 26,784 & 16,000 & N/A & 237 & N/A & 15,784 \\
\hline 2003 & 29,500 & 17,243 & 2,745 & 272 & 133 & 17,340 \\
\hline 2005 & 48,804 & 32,000 & 2,073 & 270 & 133 & 27,419 \\
\hline 2007 & 41,770 & 26,555 & 1,650 & 278 & 102 & 27,564 \\
\hline 2009 & 38,753 & 26,446 & 1,831 & 310 & 99 & 24,779 \\
\hline $2011^{\text {a) }}$ & 29,947 & 20,307 & 1,195 & 131 & 42 & 30,935 \\
\hline $2013^{\text {a) }}$ & 12,935 & 530 & 1,367 & 157 & 66 & 26,056 \\
\hline $2015^{\text {a) }}$ & 21,887 & 9,379 & 1,496 & 159 & 72 & 27,184 \\
\hline $2017^{\text {b) }}$ & 14,023 & N/A & N/A & N/A & N/A & 32,828 \\
\hline $2019^{b)}$ & N/A & N/A & N/A & 423 & N/A & 26,389 \\
\hline
\end{tabular}

Notes:

a) ... figures inclusive Pyros fair, a fair focusing on fire brigades

b)... figures inclusive Pyros and ISET fairs (ISET is a fair focusing security agencies) 
Figure 1. The Defence and Security Industry Association, 2020. ${ }^{47}$

\begin{tabular}{|c|c|c|c|c|c|}
\hline \multicolumn{2}{|l|}{ sector } & \multicolumn{2}{|l|}{ legal entity } & \multicolumn{2}{|l|}{ provenance } \\
\hline \multirow{4}{*}{ private } & \multirow{4}{*}{119} & joint-stock company & 39 & \multirow{4}{*}{$\begin{array}{l}\text { foreign } \\
\text { countries }\end{array}$} & \multirow{4}{*}{8} \\
\hline & & limited liability company & 77 & & \\
\hline & & limited partnership & 1 & & \\
\hline & & association/club & 2 & & \\
\hline public & 1 & institute & 1 & \multirow{4}{*}{$\begin{array}{l}\text { the Czech } \\
\text { Republic }\end{array}$} & \multirow{4}{*}{118} \\
\hline \multirow{3}{*}{$\begin{array}{l}\text { public - state } \\
\text { ownership }\end{array}$} & \multirow{3}{*}{6} & state university & 1 & & \\
\hline & & state-owned enterprise & 4 & & \\
\hline & & joint-stock company & 1 & & \\
\hline TOTAL & 126 & TOTAL & 126 & TOTAL & 126 \\
\hline
\end{tabular}

${ }^{1}$ Karel Kaplan, Alexej Čepička, Dobová dramata komunistické moci (Brno: Barrister \& Principal , 2011).

${ }^{2}$ Michael Sadykiewicz, The Warsaw Pact Command Structure in Peace and War (Santa Monica CA: RAND, 1988); Petr Luňák, (2007). Plánování nemyslitelného (Praha: Dokořán, 2007).

${ }^{3}$ Thomas S. Szayna, James Steinberg, Civil-Military Relations and National Security Thinking in Czechoslovakia. A Conference Report. (Santa Monica CA: RAND, 1992).

${ }^{4}$ Jeffrey Simon, NATO and the Czech \& Slovak Republics. A Comparative Study in CivilMilitary Relations (New York: Rowman \& Littlefield Publishers, 2004), chapter 2, 10.

${ }^{5}$ Zdenek Kriz, 'Army and Politics in the Czech Republic Twenty Years after the Velvet Revolution', Armed Forces \& Society, 36 (2010): 627-646.

${ }^{6}$ Gordon Adams, The Politics of Defense Contracting: The Iron Triangle (New Jersey: Transaction Publishers, 1981).

${ }^{7}$ Ibid., 1: 81 .

${ }^{8}$ Ibid., 1: 79-86.

${ }^{9}$ Karel Kaplan, Antonín Novotný: Vzestup a pád ,,lidového “apartčíka (Brno: Barrister \& Principal, 2011): 135. 
${ }^{10}$ Lubomír Štrougal, Paměti a úvahy (Praha: Epocha, 2009); Lubomír Štrougal, Ještě pár odpovědi (Praha: Epocha, 2011).

${ }^{11}$ Josef Fučík, 'Soumrak tankového věku (výroba tanků v Československu v letech 19531990)', Vojenské rozhledy. 2, no. 4 (1993): 14-24.

${ }^{12}$ Vladimír Francev, Československé tankové síly 1945-1992 (Praha: Grada, 2012).

${ }^{13}$ Ibid., 1: 88; Luboš Zahradník, Půlstoletí MiGů: budování československého a českého vojenského proudového letectva (Praha: Ministerstvo obrany, 2005).

${ }^{14}$ Ibid., 9: 139.

${ }^{15}$ Karel Kaplan, Rada vzájemné hospodářské pomoci a Československo 1957-1967 (Praha: Nakladatelství Karolinum, 2002): 224-232.

${ }^{16}$ SIPRI Yearbook 1993 (Oxford: Oxford University Press, 1993): 444, 470-475.

${ }^{17}$ Magdalén Leichtová, Linda Piknerová, Rozvojová spolupráce východního bloku v době studené války (Praha: Dokořán, 2013): 36-37.

${ }^{18}$ Jan Štaigl, Peter Turza, 'Zbrojná výroba na Slovensku v rokoch 1969-1992 1. čast”, Vojenská história. 17, no. 2 (2013): 75-112; Jan Štaigl, Peter Turza, 'Zbrojná výroba na Slovensku v rokoch 1969-1992 2. čast”, Vojenská história. 17, no. 3 (2013): 77-109; Martin Chovančík, 'Defense industrialization in small countries: Policies in Czechia and Slovakia.' Comparative Strategy, 37 (2018): 272-285.

${ }^{19}$ Josef Fučík, Konverze a zkušenosti české a slovenské federace, seminár̆ o konverzy obrany, Kodan̆, 6. - 9. 1. 1992 [manuscript - a national paper delivered to interpreters].(Praha: Federální ministerstvo hospodářství, 1992); Thomas S. Szayna, The Military in a Post-Communist Czechoslovakia (Santa Monica CA: RAND, 1992).

${ }^{20}$ Vladimír Čech, Vladimír Klaban, Výzkum a vývoj modelu hodnocení efektivnosti zbrani a výzbroje. [the final report on the researh project GAČR č. 101/01/0377] (Brno: Akademia, o.p.s, 2002). 
${ }^{21}$ Ivan Baláž, K čj. 110/6-30 SŘKČ, 7. 2. 1992, Konkrétni postup transformce a privatizace jednotlivých podniků v pưsobnosti FMO, (Praha: Federální ministerstvo obrany, 1992); Karel Pezl, Čj., 089/31/12-14, 10. 11. 1992, Informační zpráva pro zmocněnce vlády České republiky: Řě̌eni smluvních vztahů na uchováni výrobnich schopností po zániku federace. (Praha: Federální ministerstvo obrany/Generální štáb Československé armády,1992).

${ }^{22}$ Andrew Feinstein, The Shadow World. Inside the Global Arms Trade (London: Hamish Hamilton, 2011).

${ }^{23}$ Thomas, S. Szayna, The Czech Republic. A Small Contributor or a „Free Rider"? In Andrew A. Michta, America's New Allies. Poland, Hungary, and the Czech Republic in NATO. (Washington: University of Washington Press, 1999).

${ }^{24}$ Vladimír Šmejkal, 'Kam míríi 4 kola armádního vozu’, Ekonom. 39, no. 2 (1995): 27-34.

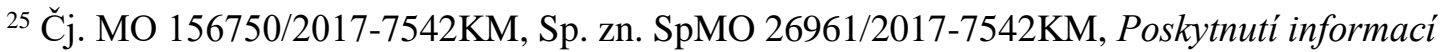
podle § 14 odst. 5 písm. d) zákona č. 106/1999 Sb., o svobodném př́stupu k informacím, ve znění zákona č. 61/2006 Sb. (Praha: Ministerstvo obrany, 2017).

${ }^{26}$ Informační bulletin Ministerstva obrany pro výrobce z českého průmyslu. (Praha: Ministerstvo obrany, 1994).

${ }^{27}$ Alex Maskalík, Elita armády. Československá vojenská generalita 1918-1992. (Banská Bystrica: HWSK, 2012).

${ }^{28}$ Vladimír Marek, 'Před odchodem. Hovoříme s generálem K. Kubou', A-report, 6, no. 22 (1996): 5 .

${ }^{29}$ Miroslav Kalousek a 20 let jeho úrednických a politických her, (Brno: Tribun EU, 2014).

${ }^{30}$ Vladimír Marek, 'Obranyschopnost, to není pouze armáda’, A-report, 4, no. 2 (1994): 8.

31 _ČTK-_ 'Po uzávěrce', A-report, 8, no. 10 (1988): 2.

32 -ČTK-, 'Jednala Bezpečnostní rada státu', A-report, 8, no. 22 (1988): 10.

${ }^{33}$ Charles W. Mills, The Power Elite. (Oxford: Oxford University Press, 2000).

${ }^{34}$ Edmund F. Wehrle, 'Welfare and Warfare: American Organized Labour Approaches the Military-Industrial Complex, 1949-1964', Armed Forces \& Society, 29 (2003): 525-546. 
${ }^{35}$ Ibid., 4: chapter 9, 10.

${ }^{36}$ Ibid., 3: 33.

${ }^{37}$ Bohuslav Pernica, The Czech Military Expenditures as a Government Failure, a Social Problem, and Cultural Conflict within 1993-2016. In Proceedings of the 21th International Conference Theoretical and Practical Aspects of Public Finance 2016 (Prague: Oeconomica, 2016).

${ }^{38}$ Eisenhower, D. D. Farewell Adress. In. Carrol W. Pursell, The Military Industrial Complex. (New York: Harper \& Row Publishers, 1972).

${ }^{39}$ Ivana Rusková, Jaroslav Pajer, ‘Spolupráce v pěti oblastech', A-report, 21, no. 1, (2011): 3839.

${ }^{40}$ Ibid., 29; Ibid., 22: 197-234; Zsolt Lazar, 'Success and failures of the Gripen offsets in the Visegrad Group countries', Defense \& Security Analysis, 35 (2019): 283-307.

${ }^{41}$ Thomas-Durell Young, 'Impediments to Reform in European Post-Communist Defense Institutions - Addressing the Conceptual Divide', Problems of Post-Communism 65 (2016): $161-74$.

${ }^{42}$ Ibid., 4: chapter 10, 11.

${ }^{43}$ Martina Šimková, 'The impact of population ageing on military policy', Central European Journal of Public Policy, 8 no, 2 (2010): 100-117.

${ }^{44}$ National reports on CFE equipment, (Prague: Ministry of defense, 1995-2020); Strategic documents issued by the Czech government since 1995.

${ }^{45}$ Ibid., 21.

${ }^{46}$ Annual Report, (Brno: Výstavy a veletrhy, a.s., 2002-2020).

${ }^{47}$ Defence and Security Industry Association of the Czech Republic (https://www.aobp.cz/?lang=en) 